\title{
PELUANG IKATAN DAI MUDA INDONESIA (IDMI) DALAM MEMBINA MASYARAKAT MUSLIM DI KOTA PALU
}

\author{
Muchlis A. Mahmud \\ Institut Agama Islam Negeri (IAIN) Palu \\ muchlis@iainpalu.ac.id
}

\section{Abstract}

This article discusses the dakwah method of the Indonesian Young Dai Association (IDMI) of Palu in fostering and developing the religiosity aspects of the community of Palu. Coaching is carried out to its members as well as to the general public. In carrying out its missionary activities, IDMI applied a variety of methods in fostering Muslim communities through recitation groups that were held regularly, ta'lim assemblies for women, as well as recitals held at the commemoration of Islamic holidays. Observation of da 'wah activities and interviews with the preachers affiliated with IDMI showed that this institution had an excellent opportunity in carrying out community religious development in Palu. The enthusiasm of the community to take part in the recitations organized by IDMI and the dakwah material that is inclusive provides the possibility for this institution to act as a unifying node in the heterogeneous community of Palu.

\section{Abstrak}

Artikel ini mendiskusikan metode dakwah Ikatan Dai Muda Indonesia (IDMI) Kota Palu dalam membina dan mengembangkan aspek religiusitas masyarakat Kota Palu. Pembinaan tersebut dilakukan kepada anggotanya maupun kepada seluruh masyarakat umum. Dalam menjalankan aktifitas dakwahnya, IDMI menerapkan beragam metode dalam membina masyarakat Muslim melalui kelompok-kelompok 
pengajian yang digelar secara rutin, majelis taklim untuk perempuan, serta pengajian yang dilaksanakan pada peringatan-peringatan hari besar Islam. Observasi terhadap aktifitas dakwah dan wawancara dengan para dai yang terafiliasi dengan IDMI menunjukkan bahwa lembaga ini memiliki peluang yang baik dalam melakukan pembinaan religiusitas masyarakat Kota Palu. Antusiasme masyarakat untuk mengikuti pengajian yang diselenggarakan oleh IDMI materi-materi dakwah yang bersifat inklusif memberikan kemungkinan bagi lembaga ini untuk berperan sebagai simpul pemersatu di tengah masyarakat Kota Palu yang heterogen.

Kata kunci: dakwah, peluang, Ikatan Dai Muda Indonesia, Kota Palu

DOI: 10.24239/al-mishbah.Vol14.Iss1.106

\section{A. Pendahuluan}

Aktifitas dakwah, bagi kaum Muslim, bersifat inheren dengan Islam. Oleh sebab dakwah, Islam dapat menyebar ke berbagai wilayah di dunia. Kewajiban berdakwah merupakan bagian dari perintah Tuhan kepada umat Islam yang diposisikan sebagai umat terbaik, sebagaimana yang termaktub di dalam Alquran: ${ }^{1}$

Kamu adalah umat yang terbaik yang dilahirkan untuk manusia, menyuruh kepada yang makruf, dan mencegah dari yang mungkar, dan beriman kepada Allah. Sekiranya Ahli Kitab beriman, tentulah itu lebih baik bagi mereka; di antara mereka ada yang beriman, dan kebanyakan mereka adalah orang-orang yang fasik (Q.S. Al 'Imran [3]: 110). ${ }^{2}$

Keberagaman setiap individu yang menjadi obyek dakwah (mad'ū)merupakan salah satu aspek penting yang menjadi

${ }^{1}$ Moh. Ali Azis, Ilmu Dakwah (Jakarta: Prenada Media, 2004), 37.

2 Departemen Agama RI, Al-Qur'an dan Terjemahnya (Jakarta: Departemen Agama RI, 1985), 65. 
pertimbangan pada dai dalam menampaikan pesan dakwahnya. Setiap dai dihadapkan pada kenyataan bahwa para penerima pesan dakwah berasal dari latar belakang pemikiran dan pengalaman kepribadian yang beragam. Keberagaman obyek dakwah, pada kelanjutannya, membentuk corak tersendiri, yang berbeda, pada tiaptiap aktifitas dakwah. Guna mengefektifkan aktifitas dakwah, setiap dai dituntut untuk memahami karakteristik obyek yang didakwahi, termasuk memahami kondisi dan lingkungan di sekitarnya di man dakwah dilangsungkan. ${ }^{3}$

Sejalan dengan pluralitas obyek dakwah di atas, dakwah sebaiknya dikemas dengan dengan metode yang tepat, sehingga pesan yang aktual, faktual, dan kontekstual. Aktual dalam pengertian bahwa pemecahan masalah sosial dan keagamaan yang ditawarkan oleh dai harus memiliki sifat kebaruan atau kekinian. Sedangkan faktual mewakili pengertian bahwa pesan yang disampaikan harus bersifat konkret dan nyata. Adapun yang dimaksud dengan kontekstual adalah dakwah yang memuat makna dan nilai yang relevan menyengkut problem yang sedang marak dihadapi oleh masyarakat. ${ }^{4}$

Ikaatan Dai Muda Indonesia (IDMI) Kota Palu merupakan lembaga dakwah yang didirikan dengan tujuan menjadi wadah bagi para dai muda di kota tersebut untuk menyebarkan gagasan serta membangun kapasitas umat Islam dengan menerapkan berbagai macam model dan pendekatan dakwah. Pemilihan Kota Palu sebagai lokasi pendirian lembaga ini dianggap relevan, mengingat tingkat konflik horizontal yang masih sering terjadi. Selain itu, problem interaksi antar sesama umat Islam, terutama berkaitan dengan isu radikalisme, dan hubungan antar umat Islam dengan pemeluk agama

${ }^{3}$ Lalu Muchsin Effendi Faizah, Psikologi Dakwah (Jakarta: Rahmat Semesta, 2006), 36.

${ }^{4}$ Asmuni Syukir, Dasar-dasar Strategi dalam Islam (Surabaya: AlIkhlas, 1983), 17. 
lainnya merupakan salah satu isu sosial yang seringkali menjadi perhatian serius di Kota Palu.

Dengan paradigma kualitatif berdasarkan data-data yang dikumpulkan melalui observasi, dokumentasi, dan wawancara, artikel ini mendeksripsikan bentuk-bentuk persuasi penyampaian pesan keagamaan yang diterapkan oleh IDMI dalam menjalankan perannya melalui gerakan-gerakan dakwah dalam pembinaan masyarakat Muslim di Kota Palu. Pada bagian akhir, artikel ini menganalisis peluang pengembangan IDMI di masa akan datang.

\section{B. Muslim di Kota Palu dan IDMI}

Kota Palu adalah Ibu Kota Provinsi Sulawesi Tengah dengan penduduk berjumlah 379,700 jiwa atau 12,80 persen dari total jumlah penduduk di provinsi ini. Secara keseluruhan, di Sulawesi Tengah, jumlah penduduk di Kota Palu menempati peringkat kedua terbanyak setelah Kabupaten Parigi Mautong. Pada tahun 2015, Persentase umat Islam di Kota Palu adalah 84,06 persen. Angka ini mengalami peningkatan sebesar 4 persen bila dibandingkan dengan empat tahun sebelumnya. ${ }^{5}$ Dari jumlah penduduk Muslim tersebut, terdapat masjid berjumlah 517 dan 99 musala. Pada tahun 2016, terdapat 26 ulama, 300 mubalig, 460 khatib, dan 317 penyuluh agama Islam di kota ini. ${ }^{6}$

Angka-angka statistik di atas memperlihatkan bahwa umat Islam di Kota Palu memainkan peran yang cukup dominan dalam tataran sosial dan kebudayaan. Dalam konteks inilah, Ikatan Dai Muda Indonesia (IDMI) Kota Palu diiniasasi pada akhir tahun 2017

${ }^{5}$ BPS Kota Palu, "Persentase Penduduk menurut Agama di Kota Palu, 2011-2015," diakses tanggal 26 Agustus 2017. https:/palukota.bps.go.id/statictable/2016/10/05/464/persentase-pendudukmenurut-agama-di-kota-palu-2011-2015.html.

${ }^{6}$ BPS Kota Palu (ed.), Kota Palu dalam Angka 2018 (Palu: BPS Kota Palu, 2018), 168 dan 428. 
sebagai cabang dari organisasi serupa yang berpusat di Kota Makassar, Sulawesi Selatan. Semangat generasi muda dalam merespon tantang umat Islam yang bersifat lokal merupakan alasan dasar yang melatarbelakangi pembentukan IDMI Kota Palu. Dalam konteks ini, para dai muda dianggap sebagai kelompok masyarakat yang terlibat dalam advokasi sosial yang intens, sehingga dianggap membutuhkan wadah struktural dalam bentuk organisasi komunitas religius yang mengedepankan profesionalitas, kemandirian, visioner, serta diwarnai dengan nilai-nilai etika keislaman. ${ }^{7}$

Secara normatif, sebagaimana yang tertera di dalam dokumen kelembagaan IDMI Kota Palu, organisasi ini dibentuk dengan visi menjadi lembaga profesi dai yang mampu mengoptimalkan potensi para dai dalam menegakkan nilai-nilai Islam sebagai rahmat bagi alam semesta (rahmat li al-ālaminn). Visi tersebut diejawantahkan ke dalam lima misi organisasi, yaitu:

1. Membangun pemahaman Islam berdasarkan Alquran dan sunah sesuai manhaj ulama salaf al-șālih bagi segenap umat manusia.

2. Membangun sikap hidup berislam yang rahmat li al-álamin.

3. Menyebarkan, mengamalkan dan membela nilai-nilai Islam.

4. Meningkatkan persaudaraan antar umat Islam (ukhuwah islamiah) antara umat.

5. Meningkatkan kemampuan dan peran dai dalam kehidupan berbangsa dan bernegara. ${ }^{8}$

Pada tataran implementasi, sebagai tindaklanjut dari visi dan misi yang telah dirumuskan, IDMI Kota Palu bergerak dalam tujuh bidang keagamaan dengan fokus pada dinamika dakwah di wilayah pendampingannya, antara lain:

\footnotetext{
${ }^{7}$ Dokumen IDMI Kota Palu 2017.

${ }^{8}$ Ibid.
} 
1. Mengembangkan potensi dai dalam mengembangkan amanat penyebaran dakwah kepada masyarakat dalam rangka terealisasinya Islam rahmat li al- ‘alamin.

2. Menjalin kerjasama dengan lembaga-lembaga dakwah Islam dan organisasi lainnya untuk mengembangkan kegiatan sosial, budaya, intelektual, dan ekonomi di Kota Palu.

3. Mengembangkan kelembagaan pendidikan Islam, antara lain dengan meningkatkan SDM (Sumber Daya Manusia) pendidikan dan para peserta didik.

4. Meningkatkan keterlibatan dai Muslim dalam kegiatan pendalaman keagamaan dan pembinaan umat.

5. Memberikan sumbangan pemikiran dalam mengambangkan sistem pendidikan pada lembaga-lembaga pendidikan terutama pesantren-pesantren dan lembaga pendidikan lembaga Islam.

6. Menyelenggarakan dan mengupayakan beasiswa bagi pelajar dan mahasiswa muslim.

7. Menyelenggarakan takaful dai

Ditinjau dari aspek struktur organisasi, kepengurusan IDMI Kota Palu pada umumnya diisi oleh alumni-alumni Jurusan Komunikasi dan Penyiaran Islam, Institut Agama Islam Negeri (IAIN) Palu. Selain aktif berdakwah di masjid-masjid yang berada di sekitar Kota Palu, beberapa di antara para pengurus tersebut juga beraktifitas sebagai dosen di almamaternya, Universitas Alkhairaat, dan Universitas Muhammadiyah Palu.

Menurut Ketua Umum IDMI Kota Palu, Ambo Illang, aktifitas mengajar di kampus-kampus Islam di Kota Palu merupakan bagian dari aktualisasi pengetahuan dan gagasan dakwah islamiah.

Beberapa di antara pengurus IDMI yang beraktifitas sebagai dosen, pada umumnya, dipercaya untuk mengampu mata kuliah keislaman. Khusus di IAIN Palu, pengurus IDMI yang juga merupakan dosen dipercaya mengampu mata kuliah yang 
berhubungan dengan dakwah, seperti strategi dakwah, metode dakwah, ilmu dakwah, dan sejenis. ${ }^{9}$

Dalam konteks dakwah, sejak didirikan, IDMI telah menjalankan sejumlah program rutin yang diselenggarakan di masjidmasjid Kota Palu. Program-program tersebut adalah bimbingan tahsin Alquran dalam rangka meningkatkan kapasitas membaca Alquran di masyarakat, kajian tafsir Alquran, kajian fikih Islam untuk remaja, dan bina remaja Muslim. Dari keempat aktifitas rutin tersebut, sebagai organisasi yang diisi oleh generasi muda, terlihat bahwa IDMI telah menentukan fokus obyek dakwahnya kepada generasi muda, terutama kalangan remaja di Kota Palu.

Selain keempat kegiatan rutin yang telah berjalan di atas, distribusi dai yang tergabung dalam IDMI melalui mimbar khutbah Jumat merupakan agenda kegiatan organisasi yang telah berjalan sejak IDMI dibentuk. Hingga hari ini, terdapat 10 masjid di Kota Palu yang, setiap Jumat, menjadwalkan anggota IDMI untuk menyampaikan ceramah pada kesempatan salat Jumat. Angka tersebut memang belum disgnifikan bila dibandingkan dengan total masjid di Kota Palu yang berjumlah 517 buah. Usia yang masih baru boleh jadi merupakan alasan hingga cakupan masjid yang memberikan jadwal rutin masih dalam jumlah terbatas. Akan tetapi, hal yang perlu digarisbawahi dari kegiatan rutin gagasan IDMI Kota Palu ini adalah inisiatif penetapan kerjasama yang dijalin antara organisasi dakwah dengan masjid-masjid lokal.

Para ahli di bidang ilmu dakwah merumuskan tiga pendekatan dakwah, yakni hikmah atau kebijaksanaan, pelajaran yang baik (maw'izah hasanah), dan diskusi dengan cara yang baik (mujādalah).

${ }^{9}$ Ambo Illang, Wawancara oleh penulis. Perekam ponsel. Kota Palu, 19 Desember 2017. 
Menurut M. Arifin, ketiga pendekatan ini disandarkan pada ayat Alquran berikut: ${ }^{10}$

Serulah (manusia) kepada jalan Tuhan-mu dengan hikmah dan pelajaran yang baik dan bantahlah mereka dengan cara yang baik. Sesungguhnya Tuhanmu Dialah yang lebih mengetahui tentang siapa yang tersesat dari jalan-Nya dan Dialah yang lebih mengetahui orang-orang yang mendapat petunjuk.

Telaah berdasarkan bentuk-bentuk dakwah yang diaplikasikan oleh para dai muda yang tergabung di IDMI Kota Palu, tampak bahwa dai-dai IDMI menerapkan sejumlah pendekatan dakwah, yaitu:

1. Pendekatan personal, yaitu dakwah dengan sasaran terdiri dari individu-individu yang terdekat, seperti saudara, orang tua, dan sahabat. Dakwah dengan pendekatan ini dilakukan melalui silaturahim dan membina hubungan yang akrab, humanis, dilandasi dengan nilai-nilai dan etika keislaman.

2. Pendekatan pendidikan. Para dai yang tergabung di oraganisasi IDMI menganggap pendidikan, berikut lembaga kependidikan, sebagai salah satu dari basis dakwah. Pendekatan ini dianggap sesuai dengan contoh dari sirah kenabian Muhammad saw. yang memberikan pendidikan kepada para sahabatnya bersamaan dengan penyebaran Islam. Oleh sebab itu, dai-dai IDMI didorong untuk terlibat secaa aktif di dalam lembaga-lembaga pendidikan Islam di Kota Palu, seperti pesantren, yayasan, madrasah, hingga perguruan tinggi keislaman. Keterlibatan ini tidak selalu dalam kapasitas sebagai pendidik, melainkan dapat pula sebagai tenaga kependidikan.

3. Pendekatan diskusi. Dialog antara dai dan mad'ū dipahami sebagai salah satu pendekatan yang efektif, sehingga para dai IDMI

${ }^{10}$ M. Arifin, Ilmu Pendidikan Islam (Jakarta: Bumi Aksara, 1990), 147. 
Kota Palu tampak cukup sering menggunakan pendekatan ini, seperti di dalam kesempatan program dialog keislaman di radio-radio lokal Kota Palu atau pada forum pengajian, seperti halāqah atau forumforum diskusi yang kerap dilaksanakan di perguruan tinggi.

4. Pendekatan hari besar Islam. Dai-dai IDMI Kota Palu diklaim tidak pernah melewatkan kesempatan berceramah pada momentum hari-hari besar Islam, misalnya hari raya, baik Idul Fitri maupun Idul Adha, Isra Mikraj, Halal bi Halal, serta perayaan Maulid Nabi Muhammad saw. Menurut Illang, salah satu alasan IDMI memanfaatkan hari besar Islam adalah karena umat Islam di Kota Palu dapat berkumpul dalam jumlah yang masif pada momentummomentum tersebut. ${ }^{11}$

5. Pendekatan misi organisasi, yaitu dengan mendelegasikan daidai IDMI ke kabupaten-kabupaten di Provinsi Sulawesi Tengah. Dalam konteks ini, Dewan Pengurus Harian IDMI Kota Palu, Hairuddin Cikka, menjelaskan bahwa pendelegasian yang dilakukan oleh IDMI berbeda dengan model pendelegasian yang berlaku di komunitas Jamaah Tabligh, karena pendelegasian oleh IDMI Kota Palu dilakukan berdasarkan undangan dari masyarakat Muslim. Pendelegasian IDMI juga tidak terbatas pada dai-dai yang tergabung di dalamnya. Dalam sejumlah kegiatan keislaman, IDMI dapat mendelegasikan anggotanya untuk terlibat dalam kepanitian agar acara keislaman yang dilangsungkan dapat terselenggara dengan baik, meskipun kegiatan tersebut diselenggarakan oleh komunitas atau organisasi di luar IDMI Kota Palu. ${ }^{12}$

\section{Peluang IDMI Kota Palu dalam Mengembangkan Religiusitas Masyarakat Kota Palu}

${ }^{11}$ Ambo Illang, Wawancara oleh penulis. Perekam ponsel. Kota Palu, 19 Desember 2017.

${ }^{12}$ Hairuddin Cikka. Wawancara oleh penulis. Perekam ponsel. Kota Palu, 23 Desember 2017. 
Pengamatan yang penulis lakukan terhadap aktifitas dakwah IDMI Kota Palu menunjukkan bawah, meski tegolong baru dibentuk, organisasi keislaman berbasis kepemudaan dan dakwah ini memiliki peluang untuk berkembang dan memperluas kontribusinya di bidang sosial dan keagamaan di Kota Palu. Program pembinaan melalui pengajian yang secara rutin telah terselenggara di masjid-masjid dan majelis taklim mendapatkan antusiasme dan respon positif dari masyarakat yang terlibat di dalamnya.

Zein MT., misalnya, memberikan apresiasi terhadap pengajian rutin yang diselenggarakan oleh IDMI Kota Palu di masjid sekitar tempat tinggalnya.

Saya senang dengan program pengajian yang diselenggarakan oleh IDMI Kota Palu ini, karena sudah sejak lama saya menantikan kegiatan-kegiatan seperti ini ada di tempat tinggal saya. Terlebih, kegiatan ini terjadwal dan dilaksanakan dengan rutin serta konsisten. Tidak seperti sebelum-sebelumnya, di mana pengajian yang diadakan berlajan rutin. Terkadang, setelah berjalan selama satu bulan, pengajian tersebut tidak berkelanjutan. Padahal, kami membutuhkan siraman rohani yang rutin dan dalam jangka panjang. ${ }^{13}$

Hal senada juga diungkapkan oleh salah seorang jamaah remaja di Kota Palu, Ahzamuddin, yang mengaku tertarik dengan model dakwah dalam bentuk pengajian rutin yang diadakan oleh IDMI Kota Palu. Dalam pandangannya, model-model pengajian yang tidak seremonial cenderung lebih mudah diterima oleh kelompok remaja di Kota Palu, terlebih bila dakwah disampaikan juga oleh dai yang masih muda serta dengan gaya pengungkapan yang khas ala anak muda di Indonesia hari ini. ${ }^{14}$

${ }^{13}$ Zein MT. Wawancara oleh penulis. Perekam ponsel. Kota Palu, 29 Desember 2017.

${ }^{14}$ Ahzamuddin, Wawancara oleh penulis. Perekam ponsel. Kota Palu, 31 Desember 2017. 
Terkait konten dakwah yang disampaikan, pilihan untuk tidak terpaku pada salah satu mazhab atau ideologi merupakan faktor yang menyebabkan pesan-pesan keagamaan yang disampaikan oleh daidai IDMI Kota Palu dapat diterima dengan baik oleh masyarakat umum.

Perasaan batin kami berbeda ketika kami mengikuti pengajian yang disampaikan oleh dai-dai IDMI, sebab materi-materi yang disampaikan tidak selalui berkaitan dengan persoalan ibadah agama, melainkan juga masalah-masalah sosial di masyarakat. Pesan-pesan yang disampaikan juga tidak terdengar eksklusif atau terpaku pada satu pemahaman, tetapi bersifat inklusif dengan merangkum macam-macam pendapat para ulama. Oleh sebab itu, sebagai jamaah pengajian, saya meminta agar IDMI pengajian ini tidak temporal dan dapat disebarluaskan ke masjid-masjid lainnya di Kota Palu. ${ }^{15}$

Temuan-temuan di lapangan yang memperlihatkan penerimaan positif dari masyarakat Muslim terhadap aktifitas dakwah IDMI Kota Palu menunjukkan bahwa organisasi ini memiliki peluang untuk berkembang dengan baik pada masa yang akan datang terlebih bila pengembangan tersebut dibarengi dengan inovasiinovasi, seperti penggunaan media sosial dan internet sebagai sarana dakwah. Hal ini dianggap penting untuk dipertimbangkan oleh IDMI Kota Palu mengingat audiens utama dari dakwah para dai di organisasi ini berasal dari kalangan remaja dan pemuda.

Sebagai bagian dari komunikasi, dakwah dianggap perlu untuk memaksimalkan media-media komunikasi terbaru yang berbasis teknologi digital. Dalam hal ini, pendekatan-pendekatan dakwah konvensional berbasis tatap muka, sebagaimana yang diterapkan oleh para dai IDMI Kota Palu, perlu dikombinasikan dengan pola-

${ }^{15}$ Abdul Hamid, Wawancara oleh penulis. Perekam ponsel. Kota Palu, 31 Desember 2017. 
pola komunikasi media digital, seperti penggunaan media sosial (Facebook, Twitter, Instagram) dan media berbagi konten video (Youtube dan IG TV).

Signifikansi penggunaan teknologi digital sebagai media dakwah dapat dilihat dari pertumbuhan pengguna internet di Indonesia. Data statistik tahn 2013 yang dilansir oleh Asosiasi Penyedia Jasa Internet Indonesia (APJII) menunjukkan bahwa 71 juta penduduk Indonesia merupakan pengguna internet aktif. Bila jumlah tersebut dikalkulasi berdasarkan persentase Muslim yang berjumlah 85 persen, maka terdapat 60 juta Muslim di Indonesia yang termasuk sebagai pengguna internet. ${ }^{16}$

\section{Kesimpulan}

Meski tergolong sebagai organisasi dakwah yang baru dibentuk, sebagai wadah bagi dai-dai muda, IDMI Kota Palu mampu memaksimalkan perannya dalam pengembangan masyarakat religius di daerah tersebut. Keragaman pendekatan dakwah, fokus pada obyek dakwah yang berasal dari kalangan remaja, kemampuan menjalin kerjasama formal dengan masjid-masjid di Kota Palu, serta kapasitas para dai yang tergabung di dalam organisasi ini terlihat merupakan faktor dominan yang menyebabkan pesan-pesan keagamaan serta kegiatan-kegiatan yang dilaksanakan oleh IDMI dapat diterima dengan baik oleh masyarakat Muslim Kota Palu.

Merujuk pada animo, antusiasme, dan respon positif terhadap aktifitas dakwah IDMI Kota Palu, dapat disimpulkan bahwa organisasi kepemudaan dan dakwah ini memiliki peluang untuk berkembang serta memberikan pengaruh signifikan kepada masyarakat, khususnya dari kalangan generasi muda. Pengembangan efek dakwah IDMI Kota Palu dapat dilakukan, salah satunya, melalui

${ }^{16}$ Nurdin, Nurdin. "World Wide Web 3.0 untuk Dakwah: Manfaat Dan Strategi Penggunaannya," Al-Mishbah: Jurnal Ilmu Dakwah dan Komunikasi 13, no. 2 (Oktober 2017), 201-227. 
Muchlis A. Mahmud, Peluang Ikatan Dai Muda Indonesia...

perluasan pendekatan. Pola dakwah konvensional dapat dikombinasikan dengan penggunaan sarana-sanara dakwah terbaru lewat pemanfaatan teknologi digital dan internet yang saat ini telah menjadi salah satu perangkat dan media yang sangat lekat di masyaraka Indonesia.

\section{Daftar Pustaka}

Azis, Moh. Ali. Ilmu Dakwah. Jakarta: Prenada Media, 2004.

BPS Kota Palu (ed.), Kota Palu dalam Angka 2018. Palu: BPS Kota Palu, 2018.

BPS Kota Palu, "Persentase Penduduk menurut Agama di Kota Palu, 20112015." Diakses tanggal 26 Agustus 2017. https://palukota.bps.go.id/statictable/2016/10/05/464/persentasependuduk-menurut-agama-di-kota-palu-2011-2015.html

Departemen Agama RI. Al-Qur'an dan Terjemahnya. Jakarta: Departemen Agama RI, 1985.

Dokumen IDMI Kota Palu 2017.

Faizah, Lalu Muchsin Effendi. Psikologi Dakwah. Jakarta: Rahmat Semesta, 2006.

Nurdin. "World Wide Web 3.0 untuk Dakwah: Manfaat Dan Strategi Penggunaannya." Al-Mishbah: Jurnal Ilmu Dakwah dan Komunikasi 13, no. 2 (Oktober 2017), 201-227.

Syukir, Asmuni. Dasar-dasar Strategi dalam Islam. Surabaya: Al-Ikhlas, 1983. 